\title{
PERSPEKTIF TEORI SOSIAL EMILE DURKHEIM DALAM SOSIOLOGI PENDIDIKAN
}

\author{
Arifuddin M Arif \\ Dosen Fakultas Tarbiyah dan Ilmu Keguruan IAIN Palu \\ arif.iainpalu@gmail.com
}

\begin{abstract}
Abstrack
This study is oriented towards Durkheim's theoretical analysis of social theories in the context of the sociology of education. This study aims to reveal the perspective and construction of Durkheim's sociological views of education and its relevance in the current social phenomena of education. With a descriptive analysis approach through literature studies, it is concluded that the dimensions of Durkheim's social theory, with the paradigm of social facts, appear in the elements forming social cohesion or social solidarity, division of labor in society, new social implications that give rise to anomie symptoms, community development and suicide (scuidi), religion and morality, and collective values. Durkheim recommends that social studies, including the study of education, be carried out according to empirical standards with a major focus on social facts. Durkheim has contributed to the construction of the education system with a sociological approach based on a functional structural approach and a theory of social facts, social solidarity, and morals. Durkheim emphasized educational buildings based on strengthening the values of collective awareness, plus providing knowledge and skills of students to survive in life.
\end{abstract}

Keywords: social theory, Emile Durkheim, education realm

\begin{abstract}
Abstrak
Kajian ini berorientasi pada analsis teoretis teori-teori sosial Durkheim dalam konteks sosiologi pendidikan. Kajian ini bertujuan mengungkap perspektif dan konstruksi pandangan sosiologi pendidikan Durkheim dan relevansinya dalam fenomena sosial pendidikan saat ini. Dengan pendekatan analisis deskriptif melalui studi literatur, maka disimpulkan bahwa dimensi teori sosial Durkheim, dengan paradigma fakta sosialnya tampak pada elemen pembentuk kohesi sosial atau solidaritas sosial, pembagian kerja dalam masyarakat, implikasi sosial baru yang melahirkan gejala anomie, perkembangan masyarakat dan bunuh diri (scuidi), agama dan moralitas, serta nilai-nilai kolektif. Durkheim merekomendasikan studi sosial, termasuk studi tentang pendidikan dilakukan menurut standar-standar empirik dengan fokus perhatian utama pada fakta sosial. Durkheim telah memberikan kontribusi terhadap konstruksi sistem pendidikan dengan pendekatan sosiologi yang berbasis pendekatan struktural fungsional dan teori fakta sosial, solidaritas sosial, serta moral. Durkheim menekankan bangunan pendidikan yang berbasis penguatan nilai-nilai kesadaran kolektif, plus pemberian pengetahuan dan skill peserta didik dalam rangka untuk survive dalam kehidupan.
\end{abstract}

Kata kunci: teori sosial, Emile Durkheim, ranah pendidikan 


\section{Pendahuluan}

Emile Durkheim, (selanjutnya; Durkheim) saat ini diakui banyak pihak sebagai "Bapak Metodologi Sosiologi", dan bahkan disebut sebagai salah satu penyumbang utama kemunculan sosiologi. Durkheim, bukan saja mampu "melejitkan" perkembangan sosiologi di Perancis, tetapi ia juga telah berhasil mempertegas eksistensi sosiologi sebagai bagian dari ilmu pengetahuan ilmiah yang memiliki ciri-ciri terukur, dapat diuji, dan objektif.

Menurut Durkheim, tugas sosiologi adalah mempelajari apa yang ia sebut sebagai "fakta-fakta sosial", yakni sebuah kekuatan dan struktur yang bersifat eksternal, tetapi mampu memengaruhi perilaku individu. Dengan kata lain, fakta sosial merupakan cara-cara bertindak, berpikir, dan berperasaan, yang berada di luar individu, dan mempunyai kekuatan memaksa yang mengendalikannya. Fakta sosial yang dimaksud di sini tidak hanya yang bersifat material, tetapi juga nonmaterial, seperti kultur, agama, atau institusi sosial. ${ }^{1}$

Durkheim percaya bahwa masyarakat dapat dipelajari secara ilmiah. Ia menolak pendekatan individual dalam memahami fenomena dalam masyarakat dan lebih memilih pendekatan secara sosial. Oleh karena itu, Durkheim juga berusaha memperbaiki metode berpikir sosiologis yang tidak hanya berdasarkan pada pemikiran-pemikiran logika filosofi tetapi juga sosiologi. Atas upayanya untuk menjadikan sosiologi sebagai sebuah disiplin ilmu yang baru inilah, Durkheim dianggap sebagai bapak sosiologi modern, selain sebutan "Bapak Metodologi Sosiologi”.

Sebagai salah satu tokoh sosiologi, Durkheim tentu mencetuskan beberapa teori-teori sosial yang kemudian dikembangkan dan diterapkan ke dalam fenomenafenomena sosial saat ini, termasuk dalam ranah pendidikan. Oleh karena itu, artikel ini akan meneliti dan menganalisis perspektif teori-teori sosial Durkheim dalam kerangka sosiologi pendidikan. Kajian ini bertujuan mengungkap perspektif dan konstruksi pandangan sosiologi pendidikan Durkheim dan relevansinya dalam fenomena sosial pendidikan saat ini. Metode yang digunakan adalah studi literatur (library research), dengan pendekatan analisis kualitatif.

\section{Metode}

Metode yang digunakan adalah studi literatur (library research), dengan pendekatan analisis kualitatif. 


\section{Pembahasan}

\section{Biografi Singkat dan Jejak Pemikiran}

Durkheim, dilahirkan pada tanggal 15 April 1858 di kota Epinal Provinsi Lorraine dekat Strasbourg, daerah Timur Laut Perancis. ${ }^{2}$ Pada usia 21 tahun, Durkheim memasuki sekolah terkenal di Ecole Normale Superieure di Paris tahun 1879. Di Universitas tersebut dia merupakan mahasiswa yang jenius, serius, dan kritis. Di sini pulalah pemikiran Durkheim terbentuk dan dipengaruhi oleh dua orang Professor terkemuka yaitu, Fustel De Coulanges dan Emile Boutroux. ${ }^{3}$

Setelah ia menamatkan pendidikan di Ecole Ormale Superieure, Durkheim mengajar Filsafat di salah satu sekolah menengah atas Lycees Louis-Le-Grand di Paris pada tahun 1882-1887. Kemudian ia juga sempat ke Jerman untuk mendalami Psikologi kepada Wilhelm Wundt. Kemudian masih pada tahun 1887, ia diangkat sebagai ahli ilmu Sosial di Fakultas Pendidikan dan Fakultas Ilmu Sosial di Universitas Bourdeaux. ${ }^{4}$

Durkheim adalah sosiolog Perancis pertama yang menempuh jenjang ilmu sosiologi paling akademis. Ia diberi posisi sebagai ilmuwan Sosial dan Pendidikan terutama dalam penelitian sosialnya. Kemudian Durkheim menetap di Jerman sampai lima belas tahun di Bordeaux, dan telah menghasilkan tiga karya besar yang diterbitkan dalam bentuk buku, tahun 1893 Durkheim menerbitkan tesis doktoralnya dalam bahasa Perancis yaitu "The Division of Labour in Society" dan tesisnya dalam bahasa Latin tentang Montesqouieu. ${ }^{5}$

Pada tahun 1902, Durkheim, diangkat sebagai professor Sosiologi dan Pendidikan di Universitas Sorbonne, Paris. Perhatian dan minat Durkheim terhadap agama yang pengaruhnya terhadap kehidupan sosial, diwujudkan dalam sebuah karyanya yang berjudul "Les Formes Elementaires de Lavie Relegieuse: Le Systeme Totemique En Australie (1912)". Buku ini diterjemahkan dalam bahasa Inggris oleh Joseph Ward Swain menjadi "The Elementary of the Religious Life" (1915). ${ }^{6}$ Dalam buku ini mencoba menemukan elemen-elemen dasar yang membentuk semua agama. ${ }^{7}$ Oleh karena itu, Durkheim mengemukakan klaim utamanya tentang arti penting teori agama dan pengaruh utama klaim ini pada pemikir-pemikir lainnya secara panjang lebar yang tertuang dalam karya besar tersebut.

Ada beberapa sumber penting yang menjadi latar belakang yang menentukan jalan pikiran Durkheim, antara lain adalah Auguste Comte (1798-1857). Selain Comte, Durkheim juga dipengaruhi dan mengikuti tradisi yang digariskan oleh Saint

2S. Lukes, Emile Durkheim: His Life and Work (Harmonds Worth:Penguin Books, 1978), 159.

${ }^{3}$ Daniel L. Seven Theories of Religion (New York: Oxford University Press, 1996), 91

4Damsar, Pengantar Teori Sosiologi (Jakarta: PT Kencana Prenada Mulia, 2015), 81.

5Peter Beilharz, Teori-Teori Sosial: Observasi Kritis terhadap Para Fiosof Terkemuka (Yogyakarta: Psutaka Pelajar, 2015), 102

'Peter Beilharz, Teori-Teori Sosial...., 104.

${ }^{7}$ Emile Durkheim, The Elementary Forms of Religions Life, terj. Inyak Ridwan Muzir, Sejarah Agama (Yogyakarta: Ircsod, 2003). 
Simon, Ernets Renan dan gurunya sendiri Fustel de Coulanges. Selain itu, situasi dan kondisi Perancis modern yang mengalami revolusi besar pada akhir tahun 1800-an juga ikut memberikan pengaruh tersendiri bagi perkembangan pemikiran Durkheim. ${ }^{8}$

Pengaruh Comte, pada pemikiran-pemikiran Durkheim, diantaranya yang tampak pada pola "reorganisasi masyarakat" yang dikemukakan oleh Comte yang kemudian disempurnakan oleh Durkheim. Durkheim melihat konsep Comte cenderung bersifat "spekulatif' dan "pragmatis". Durkheim berusaha membenahi kelemahan-kelemahan pemikiran Comte tersebut dengan berusaha tetap menjaga tujuan umum yang dikehendaki oleh Comte.

Menurut Durkheim, secara khusus ilmu sosial dapat diterapkan pada masalah penetapan kembali tatanan sosial diambang pergolakan-pergolakan revolusioner abad ke-18 dan efek-efek industrialisasi yang merugikan masyarakat. Durkheim berharap untuk memperlihatkan bagaimana sebuah konsensus sosial baru dapat menciptakan kembali nilai-nilai komunitas dan tatanan sosial, tanpa mengorbankan emansipasi manusia yang berasal dari keambrukan feodalisme. ${ }^{9}$

Dengan mengadopsi kerangka organis yang dikemukakan Comte yang berwatak positivis, maka pemikiran Durkheim pun kental dengan nuansa positivis. Sebab ciri khas pemikiran positivisme Durkheim adalah usaha satu-satunya untuk mendekati masyarakat sebagai sebuah kenyataan organis yang independen yang memiliki hukum-hukumnya sendiri.

Metodologi Durkheim berkaitan dengan sebuah pendirian yang sangat deterministik yang berpendapat bahwa individu-individu tidak berdaya di hadapan pembatasan-pembatasan dari kekuatan sosial yang menghasilkan penyesuaian diri dengan norma-norma sosial atau tingkah laku yang disebabkan oleh norma sosial tersebut. Durkheim juga mengkombinasikan pengambilan jarak ilmiah dan determinisme kausal dengan kepercayaan bahwa ilmu masyarakat memberi semacam jawaban untuk masalah-masalah etis normatif dari filsafat tradisional. Implikasi pandangan "positivistik" Durkheim terhadap "moral dalam terapan" kemudian dikategorikan sebagai "fakta sosial". Durkheim mempunyai pandangan bahwa fakta sosial jauh lebih fundamental dibandingkan dengan fakta individu.

\section{Teori-Teori Sosial Durkheim}

\section{Teori Fakta Sosial}

Durkheim mengembangkan konsep masalah pokok sosiologi melalui studi empiris. Dalam The Rule of Sociological Method, Durkheim menekankan bahwa tugas sosiologi adalah mempelajari apa yang disebut sebagai fakta-fakta sosial. Ia

${ }^{8} \mathrm{KJ}$. Veeger, Realitas Sosial, (Jakarta: PT Gramedia, 1993), 140

76.

${ }^{9}$ Emile Durkheim, Sosiologi dan Filsafat, terj. Soedjono Dirdjosiswono (Jakarta: Erlangga,1989), 
membayangkan fakta sosial sebagai kekuatan (force) dan struktur yang bersifat ekseternal dan memaksa individu. ${ }^{10}$

Fakta sosial tersebut didefinisikan sebagai cara-cara bertindak, berpikir dan merasa, yang berada di luar individu dan dilengkapi atau dimuati dengan sebuah kekuatan memaksa yang dapat mengontrol individu. Fakta sosial itulah yang akan mempengaruhi setiap tindakan, pikiran dan rasa dari individu. ${ }^{11}$ Durkheim menyatakan apa yang dipikirkan adalah kebiasaan-kebiasaan, adat istiadat dan cara hidup umum manusia sebagai sesuatu yang terkandung dalam institusi, hukum, moral dan ideologi-ideologi politis.

Suatu fakta sosial merupakan setiap cara berperilaku, baik yang tetap maupun yang tidak tetap, yang mampu memberikan tekanan eksternal pada individu, atau, setiap cara bertingkah laku yang umum dalam suatu masyarakat, yang pada waktu bersamaan tidak tergantung pada manifestasi individualnya. ${ }^{12}$ Durkheim berargumen bahwa fakta-fakta sosial tidak dapat direduksi menjadi individu-individu, tetapi harus dipelajari sebagai realitasnya sendiri.

Menurut Durkheim, bagaimanapun sadarnya individu ia harus tetap melaksanakan kewajiban-kewajiban menurut bahasa, adat istiadat, kebiasaan dan hukum masyarakatnya, dimana kesemuanya itu merupakan "fakta-fakta sosial" yang tidak direkayasa atau tidak diciptakannya melainkan ia terpaksa menjalankan dan menyesuaikan diri dengan "fakta sosial" tersebut. Individu akan menerima konsekuensi- konsekuensi penolakan sosial dan menerima hukuman. Maka dari sini ada sebuah unsur idealisme sosiologis yang jelas dalam teori Durkheim.

Durkheim juga mempunyai pandangan bahwa fakta sosial jauh lebih fundamental dibandingkan dengan fakta individu. Menurut Durkheim adalah sia-sia belaka apabila menganggap mampu memahami apa sebenarnya individu itu hanya dengan mempertimbangkan faktor biologis, psikologis atau kepentingan pribadinya. Seharusnya individu dijelaskan melalui masyarakat dan masyarakat dijelaskan dalam konteks sosialnya.

Di dalam The Rule of Sociological Method, Durkheim menjelaskan bahwa pada dasarnya ada dua tipe fakta sosial yang akan berpengaruh di dalam masyarakat, yaitu material dan non material. ${ }^{13}$ Meskipun ia membahas kedua tipe fakta sosial ini dalam karyanya, namun perhatian utamanya lebih tertuju pada fakta sosial non material (misalnya kultur, institusi sosial) ketimbang fakta sosial material (birokrasi, hukum). ${ }^{14}$

${ }^{10}$ Emile Durkheim, The Rules of Sociological Method (New York: Free Press, 1895). Lihat pula, George Ritzer, Doglas J. Goodman, Teori Sosiologi Modern (Jakarta: Kencana Prenada Media, 2007), h. 21.

${ }^{11}$ Damsar, Pengantar Sosilogi Pendidikan (Jakarta: PT Kencana Prenada Media, 2011), 29.

${ }^{12}$ Soerjono Soekanto, Mengenal Tujuh Tokoh Sosiologi Jakarta: PT Raja Grafindo Persada, 2012), 94.

${ }^{13}$ Emile Durkheim, The Role of Sociological Methode....., 156.

${ }^{14}$ George Ritzer dan Douglas J. Goodman, Teori Sosiologi Modern...., 22. 
Tipe fakta sosial material lebih mudah dipahami karena bisa diamati. Fakta sosial material tersebut sering kali mengekspresikan kekuatan moral yang lebih besar dan kuat yang sama-sama berada di luar individu dan memaksa mereka. Kekuatan moral inilah yang disebut dengan fakta sosial non material. Durkheim mengakui bahwa fakta sosial nonmaterial memiliki batasan tertentu, ia ada dalam fikiran individu. Akan tetapi dia yakin bahwa ketika orang memulai berinteraksi secara sempurna, maka interaksi itu akan mematuhi hukumnya sendiri. Individu masih perlu sebagai satu jenis lapisan bagi fakta sosial nonmaterial, namun bentuk dan isi partikularnya akan ditentukan oleh interaksi dan tidak oleh individu. Oleh karena itu dalam karya yang sama Durkheim menulis bahwa hal-hal yang bersifat sosial hanya bisa teraktualisasi melalui manusia, mereka adalah produk aktivitas manusia. Jenisjenis fakta non material, yakni moralitas, kesadaran kolektif, representasi kolektif, arus sosial, dan pikiran sosial.

\section{Teori Solidaritas Sosial}

Solidaritas menjadi bagian yang penting dalam hubungan antara individu dengan masyarakat. Durkheim membedakan dua macam solidaritas, yaitu solidaritas mekanis dan solidaritas organis. ${ }^{15}$

\section{a. Solidaritas Mekanis}

Solidaritas mekanis adalah bentuk solidaritas yang didasarkan pada suatu kesadaran kolektif yang dimiliki individu-individu yang memiliki sifat-sifat dan polapola normatif yang sama. Ciri dari solidaritas mekanik adalah tingkat homogenitas individu yang tinggi dengan tingkat ketergantungan antar individu yang sangat rendah. ${ }^{16}$ Hal ini dapat dilihat misalnya pada pembagian kerja dalam masyarakat. Dalam solidaritas mekanis, individu memiliki tingkat kemampuan dan keahlian dalam suatu pekerjaan yang sama sehingga setiap individu dapat mencukupi keinginannya tanpa tergantung dengan individu lain.

Solidaritas mekanis dibentuk oleh hukum represif (pelaku suatu kejahatan atau perilaku menyimpang akan terkena hukuman, dan hal itu akan membalas kesadaran kolektif yang dilanggar oleh kejahatan itu). Anggota masyarakat jenis ini memiliki kesamaan satu sama lain, dan karena mereka cenderung sangat percaya pada moralitas bersama, apapun pelanggaran terhadap sistem nilai bersama tidak akan dinilai main-main oleh setiap individu. Pelanggar akan dihukum atas pelanggarannya terhadap sistem moral kolektif. Meskipun pelanggaran terhadap sistem moral hanya pelanggaran kecil namun mungkin saja akan dihukum dengan hukuman yang berat.

b. Solidaritas Organis

Seiring dengan perkembangan masyarakat, dan terjadi suatu pembagian kerja yang semakin kompleks, solidaritas kemudian berubah menjadi solidaritas organik. Solidaritas ini didasarkan pada tingkat saling ketergantungan yang tinggi akibat semakin beragamnya pembagian kerja sehingga memunculkan spesialisasi pekerjaan.

\footnotetext{
${ }^{15}$ Damsar, Pengantar Sosilogi Pendidikan..., 32.

${ }^{16}$ Ibid.
} 
Masing-masing individu memiliki suatu keahlian dan keterampilan tertentu dalam suatu pekerjaan sehingga tanpa kehadirannya akan mengakibatkan individu lain tidak dapat mencukupi keinginannya.

Masyarakat solidaritas organik dibentuk oleh hukum restitutif (ia bertujuan bukan untuk menghukum melainkan untuk memulihkan aktivitas normal dari suatu masyarakat yang kompleks). ${ }^{17}$ Dimana seseorang yang melanggar harus melakukan restitusi untuk kejahatan mereka, pelanggaran dilihat sebagai serangan terhadap individu tertentu atau sekmen tertentu dari masyarakat bukannya terhadap sistem moral itu sendiri. Dalam hal ini, kurangnya moral kebanyakan orang tidak melakukan reaksi secara emosional terhadap pelanggaran hukum.

Durkheim berpendapat masyarakat modern bentuk solidaritas moralnya mengalami perubahan bukannya hilang. Dalam masyarakat ini, perkembangan kemandirian yang diakibatkan oleh perkembangan pembagian kerja menimbulkan kesadaran-kesadaran individual yang lebih mandiri, akan tetapi sekaligus menjadi semakin tergantung satu sama lain, karena masing-masing individu hanya merupakan satu bagian saja dari suatu pembagian pekerjaan sosial.

Kedua tipe masyarakat di atas terdapat perbedaan. Masyarakat yang ditandai dengan solidaritas mekanik cenderung bersatu dan lebih bersifat komunal. Sedangkan dalam masyarakat organik, masing masing melakukan kegiatan dengan pembagian kerja, sehingga berbeda tugas dan tanggung jawabnya. Masyarakat dengan ciri solidaritas organik cenderung lebih individual. Untuk melihat perbedaan kedua tipe solidaritas sosial Durkheim ini dapat dilihat pada tabel berikut:

Tabel Dua Model Tipe Masyarakat Menurut Durkheim dan Implikasinya ${ }^{18}$

\begin{tabular}{|l|l|l|}
\hline \multicolumn{1}{|c|}{ Penanda } & \multicolumn{1}{|c|}{ Solidaritas Mekanik } & \multicolumn{1}{c|}{ Solidaritas Organik } \\
\hline Masyarakat & Tradisional & Modern \\
\hline Pembagian Kerja & Rendah, Generalisasi & Spesialisasi \\
\hline Sufat Hukum & Represif & Restitutif \\
\hline Kesadaran Kolektif & Tinggi & Rendah \\
\hline Aksentuasi & Persamaan Kolektif & Perbedaan Individu \\
\hline
\end{tabular}

Sumber: Diolah dari Robert MZ Lawang, dalam Zainuddin Maliki (2010:98)

\section{Teori tentang Agama}

Dalam karyanya yang terakhir, The Elementary Forms of Religious Life (1912/1965), Durkheim memusatkan perhatian pada bentuk terakhir fakta sosial non material, yakni agama. Durkheim menyimpulkan bahwa masyarakat dan agama adalah

${ }^{17}$ Damsar, Pengantar Teori Sosiologi....., 101

${ }^{18}$ Diolah dari Robert MZ Lawang, Sistem Sosial Indonesia (Jakarta: Karunika UT, 1995), 75. 
satu dan sama. Agama adalah cara masyarakat memperlihatkan dirinya sendiri dalam fakta sosial non material. ${ }^{19}$

Dalam teori ini, Durkheim mengulas sifat-sifat, sumber bentuk-bentuk, akibat, dan variasi agama dari sudut pandang sosiologis. Agama menurut Durkheim berasal dari masyarakat itu sendiri. Masyarakat selalu membedakan mengenai hal-hal yang dianggap sakral dan hal-hal yang dianggap profane atau duniawi.

Dasar dari pendapat Durkheim adalah agama merupakan perwujudan dari collective consciouness sekalipun selalu ada perwujudaan-perwujudan lainnya. Tuhan dianggap sebagai simbol dari masyarakat itu sendiri yang sebagai collective consciouness kemudian menjelma ke dalam collective representation. Tuhan itu hanyalah idealisme dari masyarakat itu sendiri yang menganggapnya sebagai makhluk yang paling sempurna (Tuhan adalah personifikasi masyarakat).

Kesimpulannya, agama merupakan lambang collective representation dalam bentuknya yang ideal, agama adalah sarana untuk memperkuat kesadaran kolektif seperti ritus-ritus agama. Orang yang terlibat dalam upacara keagamaan maka kesadaran mereka tentang collective consciouness semakin bertambah kuat. Sesudah upacara keagamaan suasana keagamaaan dibawa dalam kehidupan sehari-hari, kemudian lambat laun collective consciouness tersebut semakin lemah kembali.

\section{Teori Bunuh Diri}

Dalam bukunya yang kedua Suicide, dikemukakan dengan jelas, hubungan antara pengaruh integrasi sosial dan kecenderungan orang melakukan bunuh diri. Durkheim memiliki asusmsi mengenai fakta sosial yang melatarbelakangi fenomena bunuh diri sekaligus kenapa suatu kelompok memiliki angka bunuh diri yang lebih tinggi.

Durkheim menggunakan dua cara yang saling berhubungan untuk mengevaluasi angka bunuh diri. Pertama, dengan membandingkan suatu tipe masyarakat atau kelompok dengan tipe lain. Kedua, dengan melihat perubahan angka bunuh diri dalam sebuah masyarakat atau kelompok dalam rentang waktu tertentu. ${ }^{20}$ Jika ada perbedaan dalam angka bunuh diri antara suatu kelompok dengan kelompok lain atau dari suatu periode dengan periode yang lain, maka menurut Durkheim perbedaan tersebut adalah akibat dari perbedaan faktor-faktor sosial atau arus sosial.

Dengan angka-angka statistik dari hasil penelitiannya di beberapa negara, dia menunjukan penolakannya terhadap teori-teori lama tentang bunuh diri. Menurut Durkheim, kenyataannya orang-orang dari lapisan atas (kaya) justru lebih tinggi tingkat bunuh dirinya dibanding dengan orang-orang dari lapisan bawah (miskin). Hal itu ditunjukannya dengan mengatakan bahwa di negara-negara miskin di Eropa seperti Italia dan Spanyol, justru memiliki angka bunuh diri yang lebih rendah

${ }^{19}$ George Ritzer dan Douglas J. Goodman, Teori Sosiologi Modern...., 23.

${ }^{20}$ Damsar, Pengantar Teori Sosiologi...., 28. 
dibandingkan dengan negara-negara Eropa yang lebih makmur, seperti Prancis, Jerman, dan negara-negara Skandinavia. ${ }^{21}$

Durkheim menambahkan bahwa, jika diselidiki, sebenarnya ada pola yang lebih teratur dari pada sebab-sebab serta penjelasan-penjelasan yang diberikan oleh teori-teori terdahulu mengenai bunuh diri. Angka bunuh diri yang ditunjukkan dari suatu kelompok atau masyarakat bersumber pada keadaan masyarakat yang bersangkutan. Dengan demikian, bunuh diri harus dipelajari dengan menghubungkannya dengan struktur sosial dari masyarakat atau negara yang bersangkutan.

Durkheim, membagi tipe bunuh diri ke dalam empat macam, yaitu bunuh diri egositis, altruistis, anomik, dan fatalistis. ${ }^{22}$

\section{a. Bunub Diri Egoistis}

Tingginya angka bunuh diri egoistis dapat ditemukan dalam masyarakat atau kelompok di mana individu tidak berinteraksi dengan baik dalam unit sosial yang luas. Lemahnya integrasi ini melahirkan perasaan bahwa individu bukan bagian dari masyarakat, dan masyarakat bukan pula bagian dari individu. Lemahnya integrasi sosial melahirkan arus sosial yang khas, dan arus tersebut melahirkan perbedaan angka bunuh diri. Durkheim menyatakan bahwa ada faktor paksaan sosial dalam diri individu untuk melakukan bunuh diri, di mana individu menganggap bunuh diri adalah jalan lepas dari paksaan sosial.

b. Bunub Diri Altruistis

Bunuh diri ini makin banyak terjadi jika makin banyak harapan yang tersedia, karena dia bergantung pada keyakinan akan adanya sesuatu yang indah setelah hidup di dunia. Ketika integrasi mengendur seorang akan melakukan bunuh diri karena tidak ada lagi kebaikan yang dapat dipakai untuk meneruskan kehidupannya, begitu sebaliknya.

c. Bunub Diri Anomic

Bunuh diri ini terjadi ketika kekuatan regulasi masyarakat terganggu. Gangguan tersebut mungkin akan membuat individu merasa tidak puas karena lemahnya kontrol terhadap nafsu mereka, yang akan bebas berkeliaran dalam ras yang tidak pernah puas terhadap kesenangan. Bunuh diri ini terjadi ketika menempatkan orang dalam situasi norma lama tidak berlaku lagi sementara norma baru belum dikembangkan (tidak ada pegangan hidup). Contoh: bunuh diri dalam situasi depresi ekonomi seperti pabrik yang tutup sehingga para tenaga kerjanya kehilangan pekerjaan, dan mereka lepas dari pengaruh regulatif yang selama ini mereka rasakan.

d. Bunub Diri Fatalistis.

Bunuh diri ini terjadi ketika regulasi meningkat. Durkheim menggambarkan seseorang yang mau melakukan bunuh diri ini seperti seseorang yang masa depannya

${ }^{21}$ Umam al-Khatib Ibnu Jamil, "Pemikiran Emil Durkheim”. Jurnal Sosiologi Research. Volume 1 Nomor 1 Desember 2016.

22Ibid., Lihat juga Damsar, Pengantar Teori Sosiologi...., 30. 
telah tertutup dan nafsu yang tertahan oleh disiplin yang menindas. Contoh: perbudakan.

Dari beberapa konsep teoritis Durkheim yang telah diuraikan di atas, mempertegas bahwa pendekatan sosiologisnya yang khusus itu bertentangan dengan perspektif Herbert Spencer yang individualitis. Gambaran Spencer yang bersifat individualistik tentang kenyataan sosial sangat berbeda dengan tekanan Durkheim bahwa fakta sosial mengatasi individu. Spencer mengasumsikan bahwa masyarakat merupakan hasil persetujuan kontraktual individu-individu yang sepakat untuk mengejar kepentingan individunya. Durkheim menegaskan bahwa kemungkinan untuk merembukkan persetujuan-persetujuan kontraktual itu mengandaikan sudah adanya satu masyarakat. Orang tidak menjalin hubungan kontrakual dengan mereka yang belum memiliki ikatan sosial yang sama. Sekurang-kurangnya sudah ada konsensus moral yang berhubungan dengan sifat kontrak yang mengikat itu.

Perspektif Durkheim, persepsi individu tentang kepentingan pribadinya tidak dibentuk dalam isolasi dari sesamanya, melainkan dibentuk oleh kepercayaan bersama serta nilai-nilai yang dianut bersama orang-orang lainnya dalam masyarakat. Spencer melihat masyarakat dibentuk oleh individu-individu, sedangkan Durkheim melihat individu dibentuk oleh masyarakat.

\section{Teori Sosial Durkheim dalam Kerangka Sosiologi Pendidikan}

Dimensi teoritik yang diungkap Durkheim, kajiannya tampak pada elemen pembentuk kohesi sosial atau solidaritas sosial, pembagian kerja dalam masyarakat, implikasi sosial baru yang melahirkan gejala anomie, perkembangan masyarakat dan bunuh diri (scuidi), agama dan moralitas, nilai-nilai kolektif.

Dalam perspektif Durkheim, yang juga dikenal sebagai perspektif struktural fungsional, konsensus, harmoni dan juga teori ekuilibirium ini, memandang masyarakat dan institusi yang ada di dalamnya, seperti pendidikan, kesehatan, agama, politik, dan lain-lain, merupakan bagian yang saling bergantung. Masing-masing menjalankan fungsinya, dan memberikan sumbangan bagi terwujudnya masyarakat yang harmoni. Pendidikan, dalam konteks ini adalah salah satu bagian yang penting untuk menjaga keberlangsungan masyarakat.

\section{Fungsi Pendidikan}

Pendidikan dipersepikan oleh Durkheim sebagai satu kesatuan utuh dari masyarakat secara keseluruhan. Pendidikan sebagai dasar masyarakat menentukan proses alokasi dan distribusi sumber-sumber perubahan. Pendidikan juga dipandang sebagai institusi yang berfungsi sebagai “baby-sitting", yang bertugas agar warga masyarakat tidak ada yang memiliki perilaku menyimpang, mislanya menjadi anak jalanan, pengangguran dan berperilaku social deviant lainnya. ${ }^{23}$ 
Durkheim, menggambarkan betapa generasi muda memerlukan bantuan pendidikan untuk mempersipakan diri memasuki kehidupan di tengah masyarakat yang memiliki tata nilai tertentu. Persiapan itu perlu karena generasi muda pada dasarnya dipandang belum siap memasuki kehidupan masyarakat. Sasaran pendidikan adalah mengembangkan kekuatan fisik, intelektual dan moral yang dibutuhkan oleh lingkungan masyarakat di mana mereka berada. Selain itu, bagi Durkheim, individu juga sebagai makhluk sosial, sehingga diantara para warga masyarakat harus saling ketergantungan. Oleh karena itu, tugas mereka adalah saling bersosialisasi, berinteraksi, dan mempelajari bahasa, skill, atau adat istiadat serta nilai-nilai kolektif yang ada di masyarakat agar bisa survive. ${ }^{24}$

Durkheim yakin ada nilai dan ide utama di setiap masyarakat tentang penghargaan terhadap akal sehat, ilmu, ide dan berbagai sentimen dari dasar moralitas yang mereka berikan kepada masyarakat. Diversity atau perbedaan diakui keberadaannya, tetapi tidak terlalu dipedulikan, karena semuanya harus tunduk pada konsensus nilai dan keyakinan masyarakatnya. Kalau tidak, ia tidak akan survive.

Keyakinan dan perlunya membangun konsensus nilai inilah peran strategis pendidikan. Melalui pendidikan, menjadi instrumen sosialisasi pengalaman yang diperoleh dari internalisasi masyarakat terhadap nilai dan ide sentral masyarakat sebagai dasar perilaku yang dinilai benar dan baik. Oleh karena itu, pelanggaran terhadap internalisasi keyakinan dan nilai-nilai itu akan menimbulkan rasa bersalah dan tidak baik. Institusi pendidikan harus menempatkan diri sebagai wadah keberlangsungan sosialisasi nilai-nilai kolektif itu. Setting internalisasi nilai-nilai ini berlangsung di lingkungan keluarga, sekolah, dan masyarakat.

\section{Pendidikan: Solidaritas Sosial dan Pembagian Kerja}

Di awal telah dibahas adanya dua tipe solidaritas masyarakat dalam perspektif Durkheim, yaitu solidaritas mekanik dan solidaritas organik. Masyarakat yang ditandai dengan solidaritas mekanik cenderung bersatu karena semua orang berwatak generalis. Sedangkan dalam masyarakat organik, masing-masing melakukan kegiatan dengan pembagian kerja, sehingga berbeda tugas dan tanggung jawab. Oleh karena ada perbedaan itu lalu memunculkan kebutuhan perlunya spesialisasi. Namun demikian, membawa implikasi persaingan, lantaran masing-masing berusaha utnuk survive.

Namun, menurut Durkheim, pembagian kerja tidak bisa dielakkan. Terjadi evolusi sosial di masyarakat. Masyarakat berubah dari solidaritas mekanik atau masyarakat yang solidaritasnya berdasar ikatan tradisional, menuju masyarakat solidaritas organik, yakni masyarakat yang tumbuh berdasar pembagian kerja. Dengan spesialisasi dan pembagian kerja yang ketat, potensial menyebabkan individu terreduksi dan terisolasi, bahkan merasa tidak berguna lagi (meaningless). Manakala kemampuan survival tidak mampu dipenuhi, maka akan menimbulkan kondisi sosial

${ }^{24}$ Jeanne H. Ballantine, The Sociology of Education: A Systematic Analysis (New Jersey: Prentice Hall, 2001), 7. 
yang patologis. Patologi dalam masyarakat modern, menurut Durkheim, berupa kemerosotan moralitas yang melahirkan anomie. ${ }^{25}$

Eksistensi moralitas inilah harus masuk dalam konteks pendidikan dan pendidik harus memiliki komitmen bersama untuk mentransformasinnya, dengan memulai dari pribadi pendidik itu sendiri. Di sinilah dapat dimaklumi mengapa secara moral pendidik harus bisa di "gugu dan ditiru" (uswah al-hasanab). Pendidikan harus hadir untuk memelihara dan mencegah generasi dari kemungkinan mengidap patologi sosial modern. Oleh karena itu, pendidikan harus berfungsi sebagai pembentuk, perawat karakter atau moralitas, dan penyembuhan patologis (the healing place in the society).

Selain itu, tugas pendidikan dalam konteks masyarakat organik harus mempersiapkan peserta didik menentukan pekerjaan, karena pekerjaan menjadi soal pilihan. Pendidikan harus membangun skill dan membentuk spesialisasi. Pendidikan juga harus memberikan standar keterampilan dan kecakapan minimum yang dibutuhkan pasar dan untuk survive.

Pendidikan harus bisa menjawab tuntutan masyarakat, terutama masyarakat industri. Kurikulum harus dikonstruk agar bisa menggali pengetahuan, membentuk skill, dan memperkokoh karakter (moralitas) sehingga peserta didik dapat mengambil dalam kehidupan. Pendidikan juga diarahkan dalam rangka memperkuat kemampuan peserta didik menjalin konsensus terhadap nilai-nilai yang dibangun oleh masyarakat. Kita harus membangun kontrak sosial, membawa pandangan, dan semua pilihan, menyatu dalam norma-norma kolektif yang dikembangkan masyarakat.

\section{Pendidikan dan Kesadaran Kolektif (Moral dan Agama)}

Sebagaimana dalam perspektif fakta sosial dan solidaritas sosial, Durkheim berpandangan bahwa kesadarana kolektif ini berada di luar individu, namun memiliki daya pemaksa terhadap individu-individu sebagai anggota masyarakat. Dengan kata lain, kesadaran kolektif adalah suatu konsensus masyarakat yang mengatur hubungan sosial di antara anggota masyarakat yang bersangkutan. Kesadaran kolektif tersebut bisa berwujud aturan-aturan moral, aturan-aturan agama, aturan-aturan tentang baik dan buruk, luhur dan mulia, dan sebagainya. Kesadaran kolektif juga merupakan salah satu wujud dari fakta sosial yang berkaitan dengan moralitas bersama. ${ }^{26}$

Dari semua penjelasan tentang nilai-nilai kolektif di atas, berimplikasi kepada cara kerja dan peran praksis pendidikan. Seluruh komponen pendidik harus menyadari otoritasnya. Dalam hal ini pengemban nilai-nilai kolektif, dan pemegang tanggung jawab untuk mentransformasikan kepada peserta didik. Pendidik adalah agen utama dari moralitas anggota masyarakat. Pada konteks ini, nilai-nilai yang dikembangkan di lembaga pendidikan adalah tidak terlepas dari nilai-nilai yang

${ }^{25}$ Robert Alun Jones, Emile Durkheim: An Introduction to Four Major Work, kesimpulan di website http://durkheim.uchicago.edu/Summaries/rules.html diakses pada tanggal 10 Agustus 2018.

${ }^{26}$ Zainuddin Maliki, Sosliologi Pendidikan...., 100. 
berkembang di masyarakat, oleh karena pendidikan ada keterkaitan yang kuat dengan konteks kesadaran kolektif masyarakat.

\section{Kesimpulan}

Berdasarkan uraian-uraian yang telah dikemukakan, dapat ditarik beberapa kesimpulan sebagai berikut:

1. Durkheim telah memberikan kontribusi besar dalam mengkonstruksi metode berpikir sosiologis berdasarkan pemikiran-pemikiran filosofis menjadi ilmu pengetahuan yang benar berdasarkan fakta-fakta yang dapat diobservasi. Durkheim merekomendasikan studi sosial, termasuk studi tentang pendidikan dilakukan menurut standar-standar empirik, dengan fakta sosial sebagai fokus perhatian utama.

2. Durkheim, telah memberikan kontribusi terhadap konstruksi sistem pendidikan dengan pendekatan sosiologi yang berbasis pendekatan struktural fungsional dan teori fakta sosial, solidaritas sosial, serta moral. Durkheim menekankan bangunan pendidikan yang berbasis penguatan nilai-nilai kesadaran kolektif, plus pemberian pengetahuan dan skill peserta didik dalam rangka untuk survive dalam kehidupan.

\section{Daftar Pustaka}

Ballantine, H., Jeanne, The Sociology of Education: A Systematic Analysis. New Jersey: Prentice Hall, 2001.

Beilharz, Peter, Teori-Teori Sosial: Observasi Kritis terbadap Para Fiosof Terkemuka. Yogyakarta: Psutaka Pelajar, 2015.

Bella, Robert N., Emile Durkheim on Morality and Society. Chicago: The University of Chicago Press, 1973.

Damsar, Pengantar Sosilogi Pendidikan. Jakarta: PT Kencana Prenada Media, 2011.

Damsar, Pengantar Teori Sosiologi. Jakarta: PT Kencana Prenada Mulia, 2015.

Daniel L. Seven Theories of Religion. New York: Oxford University Press, 1996.

Diolah dari Robert MZ Lawang, Sistem Sosial Indonesia. Jakarta: Karunika UT, 1995.

Durkheim Emile, Sosiologi dan Filsafat, terj. Soedjono Dirdjosiswono. Jakarta: Erlangga,1989.

Durkheim, Durkheim, The Rules of Sociological Method. New York: Free Press, 1895. George Ritzer, Doglas J. Goodman, Teori Sosiologi Modern. Jakarta: Kencana Prenada Media, 2007. 
Durkheim, Emile, The Elementary Forms of Religions Life, terj. Inyak Ridwan Muzir, Sejarah Agama. Yogyakarta: Ircsod, 2003.

Ibnu Jamil, Umam al-Khatib, "Pemikiran Emil Durkheim". Jurnal Sosiologi Research. Volume 1 Nomor 1 Desember 2016.

Jatmiko, Sigit, Teori-teori Sosial: Observasi Kritik Terhadap Para Filosof Terkemuka. Yogyakarta: Pustaka Pelajar, 2003.

Jones, Alun, Robert, Emile Durkheim: An Introduction to Four Major Work, kesimpulan di website http://durkheim.uchicago.edu/Summaries/rules.html diakses pada tanggal 10 Agustus 2018.

Kamiruddin, "Fungsi Sosiologi Agama: Studi Profan dan Imanen Emile Durkheim". Jurnal Toleransi dan Komunikasi Umat. Volume 3, No. 02 Desember 2011.

Lukes, S., Emile Durkheim: His Life and Work. Harmonds Worth:Penguin Books, 1978.

Maliki, Zainuddin, Sosiologi Pendidikan. Yogyakarta: Gadjah Mada University Press, 2010.

Narwoko, Dwi, J. dan Bagong Suyanto, Sosiologi: Teks Pengantar dan Terapan. Cet. 3; Jakarta: Kencana Prenada Media, 2007.

Sinulingga, Paulina, Setia, "Teori Pendidikan Moral Menurut Emile Durkheim Relevansinya dengan Pendidikan Moral Anak di Indonesia". Jurnal Filsafat, Volume 26 Nomor 2 Agustus, 2016. 